\title{
Purification and Biochemical Characteristics of Fibrinolytic Enzyme from Streptomyces corcohrussi JK-20
}

\author{
You Jung Kim ${ }^{1}$, Jeong Uck Park ${ }^{1,2,3}$, Min Jeong Seo ${ }^{2,3}$, Min Jeong Kim ${ }^{1,3}$, Hye Hyeon Lee ${ }^{1,3}$ \\ Se Hun Jin ${ }^{1}$, Byoung Won Kang ${ }^{1,2,3}$, Yung Hyun Choi ${ }^{4}$ and Yong Kee Jeong ${ }^{1,2,3 *}$ \\ ${ }^{1}$ Department of Biotechnology, Dong-A University, Busan 604-714, Korea \\ ${ }^{2}$ Department of Medical Bioscience, Dong-A University, Busan 604-714, Korea \\ ${ }^{3}$ Medi-Farm Industrialization Research Center, Busan 604-714, Korea \\ ${ }^{4}$ Department of Biochemistry, College of Oriental Medicine, Dong-Eui University, Busan 614-050, Korea
}

Received March 19, 2010 / Accepted June 14, 2010

\begin{abstract}
A fibrinolytic enzyme of Streptomyces corcohrussi from soil sediment was purified by chromatography using DEAE-Sephadex A-50 and Sephadex G-50. The analysis of SDS-polyacrylamide gel suggested that the purified enzyme is a homogeneous protein and the molecular mass is approximately $34 \mathrm{kDa}$. The purified enzyme showed activity of $0.8 \mathrm{U} / \mathrm{ml}$ in a plasminogen-rich fibrin plate, while its activity in a plasminogen-free fibrin plate was only $0.36 \mathrm{U} / \mathrm{ml}$. These results suggested that the purified enzyme acts as a plasminogen activator. The fibrinolytic activity of the enzyme under the supplementation of protease inhibitors, $\varepsilon$-ACA, t-AMCHA and mercuric chloride in the enzyme reaction was less than $24 \%$, indicating that it could be modulated by the plasmin and/or fibrinogen inhibitors involved in the fibrinogen-to-fibrin converting process. As time passed, $\mathrm{Zn}^{2+}$, a heavy metal ion, inhibited the activity to $34.1 \%$. The optimum temperature of the purified enzyme was approximately $50^{\circ} \mathrm{C}$ and over $92 \%$ of the enzyme activity was maintained between $\mathrm{pH} 5.0$ and 8.0. Therefore, our results provide a potential fibrinolytic enzyme as a noble thrombolytic agent from $S$. corcohrussi.
\end{abstract}

Key words : Fibrinolytic enzyme, plasmin inhibitor, plasminogen activator, Streptomyces corcohrussi

\section{Introduction}

The typical fibrinolytic enzymes such as tissue plasminogen activator ( $t$-PA) and urokinase ( $u$-PA, EC 3.4.21.31) have been used as thrombolytic agents [3]. The fibrinolytic enzymes produced by the microbes including streptokinase [17] and staphylokinase [1] have been extensively investigated, however, they are not in a common use because of the side effects such as gastrointestinal bleeding, allergic reactions and resistance to repercussion [3,4,25]. The fibrinolytic enzymes from Bacillus spp. have also been interested in the thrombolytic agent because of a high efficiency in the fibrinolytic reactions such as plasmin activation. A variety of extracellular and intracellular proteases including Subtlisin Carsberg [22], nattokinase [19], amylosachariticus [26], aprE [20], Subtilin J [8] and BK II [9] have been produced by the Bacillus spp.

However, the enzymes such as tissue plasminogen activators, urokinase, streptokinase and staphylokinase were not

\footnotetext{
*Corresponding author

Tel : +82-51-200-7557, Fax : +82-51-510-8086

E-mail : ykj9912@dau.ac.kr
}

widely used in the medical treatment for the blood-clotting disease because of the high cost and unstable enzymatic properties in the temperature [3,4]. The fibrinolytic enzymes from the Streptomyces genus including S. megasporus were previously reported $[5,7]$, however, the effect of protease inhibitors on a fibrinolytic enzyme of the genus has not been reported. Thus, this study aimed to develop a fibrinolytic enzyme from $S$. corcohrussi, which can be modulated by the protease inhibitors for a therapeutic potential. In this paper, we report the purification of a fibrinolytic enzyme from $S$. corcohrussi and its biochemical characteristics including the effect of protease inhibitors on the fibrinolytic enzyme.

\section{Materials and Methods}

Isolation of a Streptomyces strain and culture condition

The soil sediments isolated in Busan, Korea was suspended in a $10 \%(\mathrm{w} / \mathrm{v})$ sterile sodium chloride solution. To isolate Streptomyces spp. producing a fibrinolytic enzyme, 50 $\mu \mathrm{l}$ of the diluted sample was smeared on the plate containing an ISP medium ( $\mathrm{pH} 7.5$ ) supplemented with $1 \%$ glucose, $0.1 \%$ yeast extract, $0.1 \%$ polypeptone, $0.1 \%$ beef extract and 
$1.5 \%$ agar. The colonies from the plate were aerobically cultured at $28^{\circ} \mathrm{C}$ for 4 days and the resulting culture was centrifuged for 8,000 rpm at $10 \mathrm{~min}$. The harvested cells were analyzed for the morphological, physiological and biochemical characteristics including the production of a fibrinolytic enzyme [2].

\section{Enzyme purification and SDS-polyacrylamide gel electrophoresis}

The cultured cells were removed by centrifuging at 10,000 rpm for $15 \mathrm{~min}$ and ammonium sulfate was slowly added to the supernatant up to the $75 \%$ saturation. The precipitate was harvested by centrifuging at 10,000 rpm for $15 \mathrm{~min}$ and dialyzed with 51 of $20 \mathrm{mM}$ Tris- $\mathrm{HCl}$ ( $\mathrm{pH} \mathrm{7.5)}$ five times. All purification steps were performed at $4^{\circ} \mathrm{C}$ and protein concentration was measured according to the method of Bradford [6]. The enzyme was purified by chromatography method using the DEAE-Sephadex A-50 and Sephadex G-50 gel filtration columns. In DEAE-Sephadex A-50 column, the enzyme was eluted by a linear gradient from 0.1 to $0.5 \mathrm{M}$ sodium chloride and $70 \%$ (w/v) ammonium sulfate precipitation. In Sephadex G-50 column, the enzyme was purified by gel filtration using the Tris- $\mathrm{HCl}$ buffer as an elution buffer. The enzyme solution obtained in the chromatography method was then lyophilized. SDS-polyacrylamide gel electrophoresis (PAGE) of the lyophilized protein was performed according to the method of Laemmli [15]. The $10-15 \%$ gradient polyacrylamide and $4 \%$ stacking gels were used in performing SDS-PAGE.

\section{Estimation of fibrinolytic activity}

Fibrinolytic activity was determined by fibrin plate methods [2] using plasminogen-free and plasminogen-rich plates. The plasminogen - free fibrin plate was supplemented with fibrinogen solution [ $2.5 \mathrm{ml}$ of $1.2 \%(\mathrm{w} / \mathrm{v})$ human fibrinogen (Sigma, USA) in 0.1 M sodium phosphate buffer, $\mathrm{pH}$ 7.4], $10 \mathrm{U}$ of thrombin solution (Sigma, USA) and 1\% agarose. Fibrin plates were heated at $80^{\circ} \mathrm{C}$ for $30 \mathrm{~min}$. A plasminogen-rich fibrin plate was supplemented with $1.5 \%$ fibrinogen, $5 \mathrm{U}$ of plasminogen and $1 \%$ agarose.

A hole ( $5 \mathrm{~mm}$ in diameter) was punched for sample application on the fibrin plate and the sterilized paper disc was placed on the plate. To observe fibrinolytic activity, $100 \mu \mathrm{l}$ of the purified protein solution was carefully dropped to the disc and incubated at $37^{\circ} \mathrm{C}$ for $18 \mathrm{hr}$. The activity of fibrinolytic enzyme was determined by measuring the halo zone on the fibrin plate and plotting to the standard curve.

\section{Effect of the metal ions and protease inhibitors}

The effect of metal ions including $\mathrm{Ca}^{2+}, \mathrm{Co}^{2+}, \mathrm{Cu}^{2+}, \mathrm{Mg}^{2+}$, $\mathrm{Mn}^{2+}, \mathrm{Zn}^{2+}$ and $\mathrm{Hg}^{2+}$ on the fibrinolytic activity was observed. The effect of the protease inhibitors $\varepsilon$-aminocaproic acid ( $\varepsilon$ ACA), t-4-aminomethyl-cyclohexane carboxyl acid (t-AMCHA), mercuric chloride, tosyllysine chloromethylketone (TLCK), p-chloromercuribenzonic acid (PCMB), $\rho$-tosyl-L-arginine methylester hydrochloride (TAME) and diisopropyl fluorophosphate (DIFP) on the activity was also analyzed. Fibrinolytic activity of the enzyme was measured spectrophotometrically by supplementing with the chromogenic substrate in the enzyme reaction. The reaction mixture $(1$ $\mathrm{ml}$ ) contained $20 \mu \mathrm{l}$ of enzyme solution, $5 \times 10^{-4} \mathrm{M}$ chromogenic substrate and $0.1 \mathrm{M}$ sodium phosphate buffer ( $\mathrm{pH}$ 7.4). After incubation for $5 \mathrm{~min}$ at $37^{\circ} \mathrm{C}$, the amount of liberated $p$-nitroaniline was determined from the spectrophotometric absorption at $405 \mathrm{~nm}$. One unit of amidolytic activity was expressed as $\mu \mathrm{mol}$ of the substrate hydrolyzed per min per $\mathrm{mg}$ of the protein at $25^{\circ} \mathrm{C}$.

\section{Effects of temperature and $\mathrm{pH}$ on the enzyme activity}

The optimum temperature for the enzyme activity was determined by keeping the purified enzyme in $10 \mathrm{mM}$ phosphate buffer ( $\mathrm{pH} 7.4$ ) for $30 \mathrm{~min}$ at various temperatures $\left(20,30,40,50,60,70\right.$ and $\left.80^{\circ} \mathrm{C}\right)$. The optimal $\mathrm{pH}$ of the enzyme was determined between $\mathrm{pH} 3.0-11.0$, using the following buffer systems: $0.05 \mathrm{M}$ citrate buffer ( $\mathrm{pH} 4.0$ ), 0.05 $\mathrm{M}$ sodium phosphate ( $\mathrm{pH}$ 5.0-7.0), $0.05 \mathrm{M}$ Tris- $\mathrm{HCl}$ ( $\mathrm{pH}$ 8.0-9.0) and 0.05 M glycine- $\mathrm{NaOH}(\mathrm{pH} 10.0)$, respectively. Fibrin plates of different $\mathrm{pH}$ values were prepared using different buffers. All experiments were carried out at least three times.

\section{Results}

\section{Isolation of microbial strains showing fibrinolytic activity}

Twelve microbial strains showing fibrinolytic activity were isolated in the soil sediment. Out of the strains, an isolate was identified and its physiological characteristics were investigated. Scanning electron micrograph revealed that the isolated microbe possessed an aerial mycelium and cylindrical spores showing the smooth surface (Fig. 1). The biochemical and physiological characteristics were shown in 


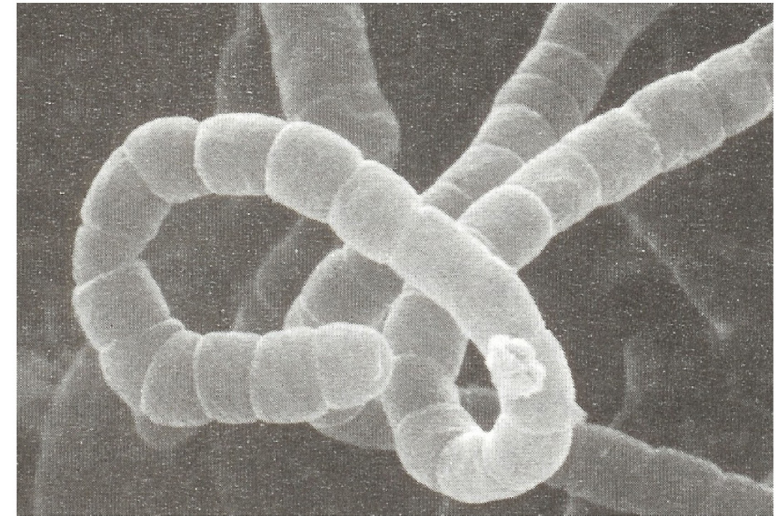

$-$

$100 \mathrm{~nm}$

Fig. 1. Scanning electron micrograph of fibrinolytic enzyme-generating Streptomyces corcohrussi JK-20.

Table 1. The strain was denoted as Streptomyces corcohrussi JK-20. A fibrinolytic enzyme was purified from the strain and the biochemical characteristics were also investigated.

\section{Purification of a fibrinolytic enzyme and SDS-PAGE}

The fibrinolytic enzyme was purified by the steps listed in Table 2. After the ammonium sulfate precipitation, ethanol precipitation, DEAE-Sephadex A-50 chromatography method and Sephadex G-50 gel filtration method were performed to purify the enzyme. As a result, the analysis of SDS-polyacrylamide gel showed only single polypeptide (Fig. 2). The apparent molecular mass of the purified fibrinolytic enzyme was estimated to be approximately 34 $\mathrm{kDa}$. The specific activity of the enzyme was 809 -folds higher than that of culture supernatant.

The proteolytic activity of the enzyme was observed by fibrin plate assay for $5 \mathrm{hr}$, respectively (Fig. 3). The fibrinolytic activity of purified enzyme in plasminogen-rich fibrin plate was more than $0.8 \mathrm{U} / \mathrm{ml}$, however, the activity in plasminogen-free fibrin plate was less than $0.36 \mathrm{U} / \mathrm{ml}$ (Fig. 3C). These results indicate that the enzyme acts as a plasminogen activator.
Table 1. Physiological characteristics of the purified fibinolytic enzyme from S. corcohrussi JK-20

\begin{tabular}{lc}
\hline Physiological characteristics & Assimilation \\
\hline Coagulation of milk & + \\
Peptonization of milk & - \\
Hydrolysis of starch & + \\
Melanoid pigment & - \\
Liquefaction of gelatin & + \\
Reduction of nitrate & - \\
Hydrolysis of starch & + \\
Assimiliation of & \\
D-Glucose & + \\
L-Arabinose & \pm \\
D-Xylose & + \\
D-Mannitol & \pm \\
D-Fructose & \pm \\
L-Rhamnose & + \\
Sucrose & \pm \\
Raffinose & + \\
D-Galactose & + \\
Cellobiose & + \\
Cellulose & + \\
Inulin & - \\
Melibiose & \pm \\
Optimum growth temperature & + \\
Optimum growth pH & $24^{\circ} \mathrm{C}$ \\
\hline
\end{tabular}

+ : assimilation, $-:$ no assimilation

\section{Effect of the protease inhibitors and the metal ions}

Influence of protease inhibitors on the fibrinolytic activity was estimated (Table 3). Relative activity of the purified enzyme on the addition of $\varepsilon$-ACA, t-AMCHA, mercuric chloride and TLCK was about 17.9, 21.2, 23.6 and 31.4\%, respectively. In addition, PCMB, TAME and DFP inhibited the activity to 45,48 and $57 \%$, respectively. These findings suggest that the fibrinolytic activity of the enzyme could be significantly reduced by the plasmin inhibitor such as $\varepsilon$ -ACA and/or presence of the multiple binding sites on the fibrinogen molecule to convert fibrin.

In addition, the effect of metal ions on the fibrinolytic activity was observed (Table 3). The addition of $\mathrm{Zn}^{2+}$ to the reaction decreased the enzyme activity by $66 \%$, whereas the addition of $\mathrm{Co}^{2+}$ to the reaction increased the activity by $31 \%$.

Table 2. Purification processes of the fibrinolytic enzyme from S. corcohrussi JK-20

\begin{tabular}{lccccc}
\hline Step & Total protein $(\mathrm{mg})$ & Total activity $(\mathrm{U})$ & Specific activity $(\mathrm{U} / \mathrm{mg})$ & Yield $(\%)$ & Folds \\
\hline Culture supernatant & 22,163 & 35,375 & 1.6 & 100 & 1 \\
Ethanol precipitation & 756.2 & 25,648 & 34 & 73 & 21.3 \\
DEAE-Sephadex A-50 & 8.6 & 4,723 & 549 & 13 & 343 \\
Sephadex G-50 & 0.4 & 518 & 1,295 & 1.4 & 809
\end{tabular}


(A)

(B)

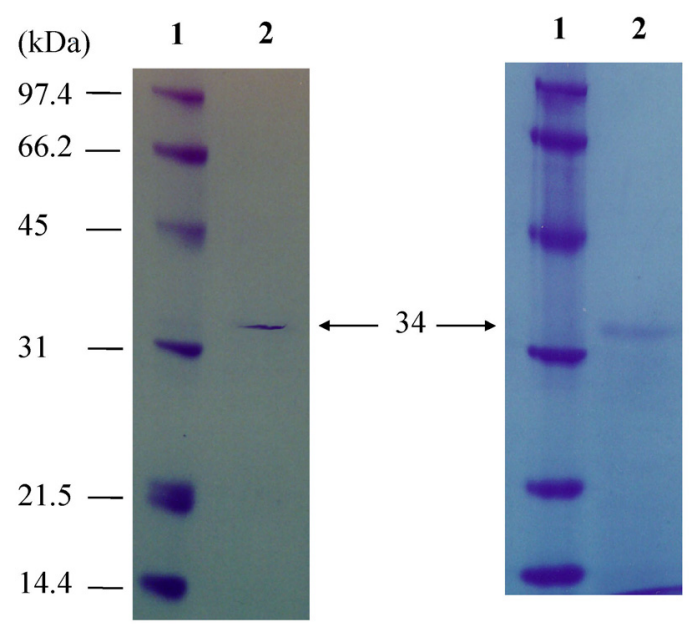

Fig. 2. Polyacrylamide gel electrophoresis of the fibrinolytic enzyme purified by DEAE-Sephadex A-50 chromatography and Sephadex G-50 gel filtration. A: enzyme from DEAE-Sephadex A-50 chromatography, B: enzyme from Sephadex G-50 gel filtration (lane 1, molecular mass markers; lane 2, fibrinolytic enzyme purified from $S$. corcohrussi JK-20). The enzyme showed only single polypeptide on SDS-PAGE gels, which was in the same position. The arrow indicates the fibrinolytic enzyme purified from the isolated Streptomyces strain.

\section{Effects of temperature and $\mathrm{pH}$ on fibrinolytic activity}

The estimation of fibrinolytic activity measured at temperature from 20 to $80^{\circ} \mathrm{C}$ showed that the activity was the highest at $50^{\circ} \mathrm{C}$ and inactivated by $40 \%$ at temperature over $70^{\circ} \mathrm{C}$ (Fig. 4A). It was also maintained over $74 \%$ for $30 \mathrm{~min}$ at temperature between 40 and $50^{\circ} \mathrm{C}$, indicating that the enzyme was significantly stable at the temperature. The enzyme remained active at $\mathrm{pH}$ values ranging from 5.0 to 10.0
Table 3. Effect of metal ions and protease inhibitors on the activity of the purified fibrinolytic enzyme

\begin{tabular}{cc}
\hline Metal ions or inhibitors & Relative activity (\%) \\
\hline None & 100 \\
$\varepsilon$-ACA & $15 \pm 2.9$ \\
t-AMCHA & $19 \pm 2.2$ \\
Mercuric chloride & $21 \pm 2.6$ \\
TLCK & $28 \pm 3.4$ \\
PCMB & $51 \pm 3.9$ \\
TAME & $48 \pm 4.2$ \\
DFP & $40 \pm 3.3$ \\
EDTA & $72 \pm 3.7$ \\
Ca & $110 \pm 4.2$ \\
$\mathrm{Co}^{2+}$ & $136 \pm 4.1$ \\
$\mathrm{Cu}^{2+}$ & $81 \pm 3.5$ \\
$\mathrm{Mg}^{2+}$ & $92 \pm 3.8$ \\
$\mathrm{Mn}^{2+}$ & $83 \pm 2.6$ \\
$\mathrm{Zn}^{2+}$ & $32 \pm 2.1$ \\
$\mathrm{Hg}^{2+}$ & $65 \pm 2.8$
\end{tabular}

The concentration of protein inhibitors and metal ions added to the reaction mixture was $1 \mathrm{mM}$.

The results are expressed as the relative percentage (\%) of the relative activity. All experiment was performed in triplicate.

(Fig. 4B). Especially, the fibrinolytic activity of the enzyme was optimal between $\mathrm{pH} 6.0$ and 8.0. However, it was significantly decreased at $\mathrm{pH}$ below 5.0. These results indicate that the enzyme purified from $S$. corcohrussi is active in a broad $\mathrm{pH}$ range.

\section{Discussion}

Many studies have reported the production of fibrinolytic enzymes [10-14,16,18,21,23,24,27] but the generation of fibrinolytic enzymes from the Streptomyces genus has not been
(A)

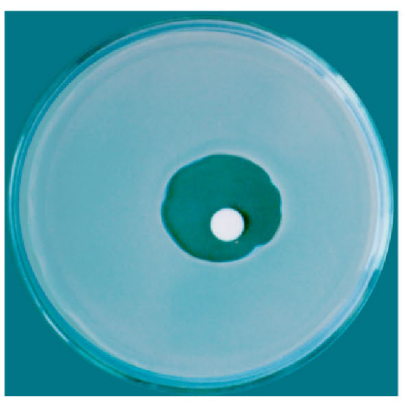

(B)

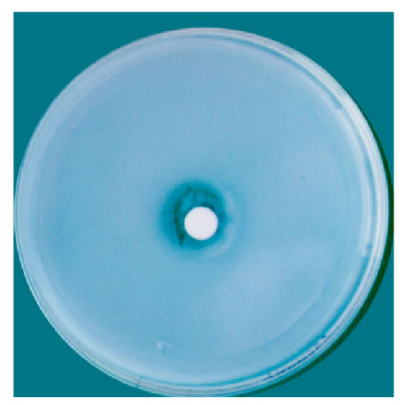

(C)

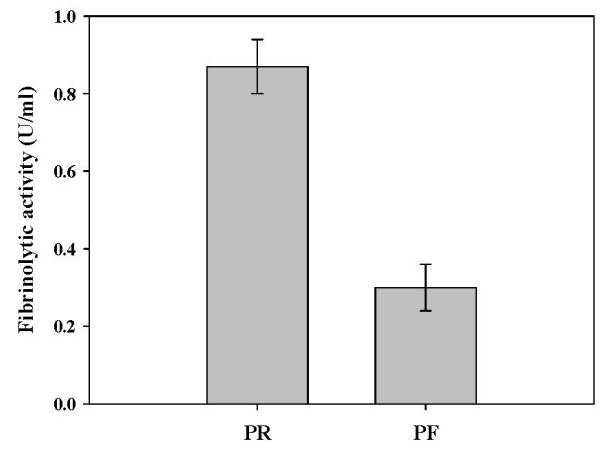

Fig. 3. Fibrinolytic activity in plasminogen-rich fibrin plate (A), plasminogen-free fibrin plate (B) and estimation of the fibrinolytic activity $(C)$. The results in $(C)$ represent the mean $\pm S D$ from the duplicate of three independent experiments. (SD: standard deviation). PR, plasminogen-rich fibrin plate: PF, plasminogen-free fibrin plate. 
(A)

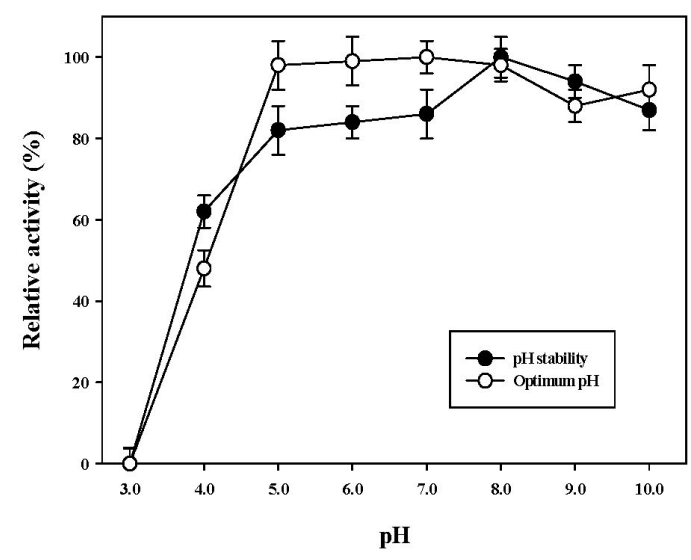

(B)

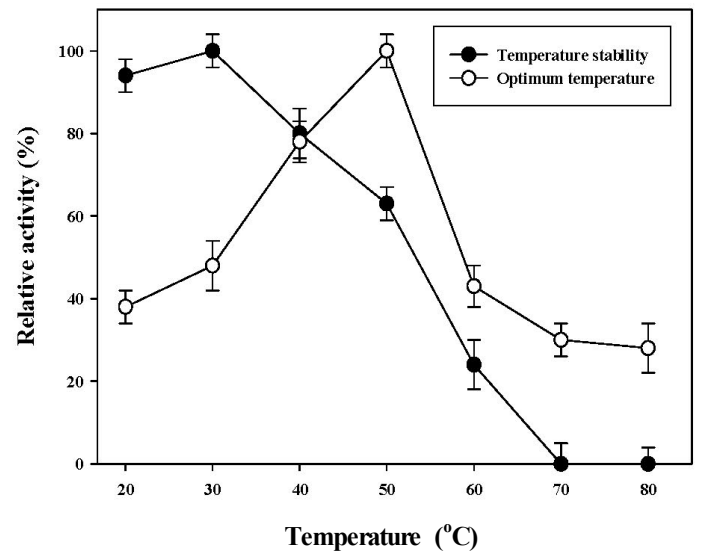

Fig. 4. Optimum temperature (A) and $\mathrm{pH}(\mathrm{B})$ of the fibrinolytic enzyme purified from $S$. corchorussi JK-20. The results represent the mean $\pm \mathrm{SD}$ from the duplicate of three independent experiments. (SD: standard deviation).

widely investigated [5,7]. For a therapeutic potential, we have newly identified S. corcohrussi capable of producing a fibrinolytic enzyme and investigated its biochemical characteristics.

Scanning electron micrograph of the isolate showed an aerial grey mycelium and the spore chain consisting of about 10-40 spores (Fig. 1). The optimum growth temperature and $\mathrm{pH}$ of S. corcohrussi JK-20 were $24^{\circ} \mathrm{C}$ and 6.0, respectively. The isolate hydrolyzed starch and coagulated milk (Table 1). An extracellular fibrinolytic enzyme of $S$. corcohrussi JK-20 was purified by the chromatography method using DEAE-Sephadex G-50 and Sephadex G-50 (Table 2). The apparent molecular weight of the enzyme obtained by SDS-PAGE was estimated to be about $34 \mathrm{kDa}$ (Fig. 2). The fibrinolytic activity in plasminogen-rich and plasminogen-free fibrin plates was over $0.8 \mathrm{U} / \mathrm{ml}$ and below $0.36 \mathrm{U} / \mathrm{ml}$, respectively (Fig. 3C). The result indicates that the fibrinolytic enzyme from the newly isolated S. corcohrussi JK-20 acts as a plasminogen activator.

In addition, effect of metal ions and protease inhibitors on the enzyme activity was estimated (Table 3 ). The addition of $\mathrm{Zn}^{2}$ and $\mathrm{Hg}^{2+}$ to the enzyme reaction decreased fibrinolytic activity by $34 \%$ and $32 \%$, respectively. Notably, the addition of $\mathrm{Co}^{2+}$ augmented the activity by $32 \%$. In a while, the addition of the protein inhibitors, t-AMCHA, mercuric chloride and TLCK to the enzyme reaction decreased the activity by 79,76 and $69 \%$, respectively. Especially, the addition of the plasmin inhibitor, $\varepsilon$-ACA in the reaction mixture inhibited the activity over $82 \%$. These results indicate that the fibrinolytic process occurring by the enzyme could down- regulated by the plasmin inhibitor and/or presence of the multiple binding domains on the fibrinogen molecule to convert fibrin. The enzyme purified from $S$. corcohrussi showed high stability at $50^{\circ} \mathrm{C}$ and its optimal $\mathrm{pH}$ ranged in 5.0 and 8.0 (Fig. 4). The enzymatic features were distinguished from the known fibrinolytic enzyme from S. megasporus strain SD5 resistant to temperature ranging from 37 to $60^{\circ} \mathrm{C}$ and the range between $\mathrm{pH} 6.0$ and 9.0 [7].

In conclusion, the fibrinolytic enzyme of $S$. corcohrussi JK-20 was isolated in the soil sediment and investigated for the biochemical characteristics. It acted as a plasminogen activator, which could degrade fibrin. Therefore, these results provide a fibrinolytic enzyme, as a noble thrombolytic agent from S. corcohrussi JK-20.

\section{Acknowledgement}

This work was supported by a Dong-A University Research Fund, Korea.

\section{References}

1. Arai, K., J. Mimuro, S. Madoiwa, M. Matsuda, T. Sako, and Y. Sakata. 1995. Effect of staphylokinase concentration of plasminogen activation. Biochim. Biophys. Acta 1245, 69-75.

2. Astrup, T. and S. Müllertz. 1952. The fibrin plate method for estimating fibrinolytic activity. Arch. Biochem. Biophys. 40, 346-351.

3. Blann, A. D., M. J. Landray, and G. Y. Lip. 2002. ABC of antithrombotic therapy: an overview of antithrombotic therapy. BMJ 25, 762-765. 
4. Bode, C., M. S. Runge, and R. W. Smalling. 1996. The future of thrombolysis in the treatment of acute myocardial infarction. Eur. Heart J. 17, 55-60.

5. Bono, F., P. Savi, A. Tuong, M. Maftouh, J. M. Pereillo, J. Capdevielle, J. C. Guillemot, J. P. Maffrand, and J. M. Herbert. 1996. Purification and characterization of a novel protease from culture filtrates of a Streptomyces sp. FEMS Microbiol. Lett. 141, 213-220.

6. Bradford, M. M. 1976. A rapid and sensitive method for the quantitation of microgram quantities of protein utilizing the principle of protein-dye binding. Anal. Biochem. 72, 248-254.

7. Chitte, R. R. and S. Dey. 2000. Potent fibrinolytic enzyme from a thermophilic Streptomyces megasporus strain SD5. Lett. Appl. Microbiol. 31, 405-410.

8. Jang, J. S., D. O. Kang, M. J. Chun, and S. M. Byun. 1992. Molecular cloning of a subtilisin J gene from Bacillus stearothermophilus and its expression in Bacillus subtilis. Biochem. Biophys. Res. Commun. 184, 277-282.

9. Jeong, Y. K., J. H. Kim, S. W. Gal, J. E. Kim, S. S. Park, K. T. Chung, Y. H. Kim, B. W. Kim, and W. H. Joo. 2004. Molecular cloning and characterization of the gene encoding a fibrinolytic enzyme from Bacillus subtilis strain A1. World J. Microbiol. Biotechnol. 20, 711-717.

10. Jeong, Y. K., J. U. Park, H. Baek, S. H. Park, and I. S. Kong. 2001. Purification and biochemical characterization of a fibrinolytic enzyme from Bacillus subtilis BK-17. World J. Microbiol. Biotechnol. 17, 89-92.

11. Jeong Y. K., W. S. Yang, K. H. Kim, K. T. Chung, W. H. Joo, J. H. Kim, and J. U. Park. 2004. Purification of a fibrinolytic enzyme (myulchikinase) from pickled anchovy and its cytotoxicity to the tumor cell lines. Biotechnol. Lett. 26, 393-397.

12. Kim, W., K. Choi, Y. Kim, H. Park, J. Choi, Y. Lee, H. Oh, I. Kwon, and S. Lee. 1996. Purification and characterization of a fibrinolytic enzyme produced from Bacillus sp. strain CK 11-4 screened from Chungkook-Jang. Appl. Environ. Microbiol. 62, 2482-2488.

13. Kim, J. H. and Y. S. Kim. 1999. A fibrinolytic metalloprotease from the fruiting bodies of an edible mushroom, Armillariella mellea. Biosci. Biotechnol. Biochem. 63, 2130-2136.

14. Kim, H. K., G. T. Kim, D. K. Kim, W. A. Chio, S. H. Park, Y. K. Jeong, and I. S. Kong. 1997. Purification and characterization of a novel fibrinolytic enzyme from Bacillus sp. KA38 originated from fermented fish. J. Ferment. Bioeng. 84, 307-312.

15. Laemmli, U. K. 1970. Cleavage of structural proteins during the assembly of the head of bacteriophage T4. Nature 227, 680-685.
16. Lee, J., S. Park, W. A. Choi, K. H. Lee, Y. K. Jeong, I. S. Kong, and S. Park. 1999. Production of a fibrinolytic enzyme in bioreactor culture by Bacillus subtilis BK-17. J. Microbiol. Biotechnol. 9, 443-449.

17. Medved, L. V., D. A. Solovjov, and K. C. Ingham. 1966. Domain structure, stability and interactions in streptokinase. Eur. J. Biochem. 239, 333-339.

18. Mihara, H., H. Sumi, T. Yoneta, H. Mizumoto, R. Ikeda, M. Seiki, and M. Maruyama. 1991. A novel fibrinolytic enzyme extracted from the earthworm Lumbricus rubellus. Jpn. J. Physiol. 41, 461-472.

19. Nakamura, T., Y. Yamagata, and E. Ichishima. 1992. Nucleotide sequence of the subtilisin NAT gene, aprN of Bacillus subtilis (natto). Biosci. Biotechnol. Biochem. 56, 18691871.

20. Park, S. S., S. L. Wong, L. F. Wang, and R. H. Doi. 1989. Bacillus subtilis subtilisin gene (aprE) is expressed from a sigma A (sigma 43) promoter in vitro and in vivo. J. Bacteriol. 171, 2657-2665.

21. Peng, Y., Q. Huang, R. H. Zhang, and Y. Z. Zhang. 2003. Purification and characterization of a fibrinolytic enzyme produced by Bacillus amyloliquefaciens DC-4 screened from douchi, a traditional Chinese soybean food. Comp. Biochem. Physiol. B 134, 45-52.

22. Smith, E. L., R. J. Delange, W. H. Evans, M. Landon, and F. S. Markland. 1968. Subtilisin Carlsberg. V. The complete sequence; comparison with subtilisin BPN ' ; evolutionary relationships. J. Biol. Chem. 243, 2184-2191.

23. Sumi, H., H. Hamada, H. Tsushima, H. Mihara, and H. Muraki. 1987. A novel fibrinolytic enzyme (Nattokinase) in the vegetable cheese natto: a typical and popular soybean food in the Japanese diet. Experimentia 43, 1110-1111.

24. Sumi, H., N. Nakajima, and C. Yatagai. 1995. A unique strong fibrinolytic enzyme (Katsuwokinase) in skipjack "Shiokara", a Japanese traditional fermented food. Comp. Biochem. Physiol. 112, 543-547.

25. Turpie, A. G., B. S. Chin, and G. Y. Lip. 2002. Venous thromboembolism: pathophysiology, clinical features, and prevention. BMJ 325, 887-890.

26. Vasantha, N., L. D. Thompson, C. Rhodes, C. Banner, J. Nagle, and D. Filpula. 1984. Genes for alkaline protease and neutral protease from Bacillus amyloliquefaciens contain a large open reading frame between the regions coding for signal sequence and mature protein. J. Bacteriol. 159, 811-819.

27. Wong, A. H. and Y. Mine. 2004. A novel fibrinolytic enzyme in fermented shrimp paste, a traditional Asian fermented seasoning. J. Agric. Food Chem. 52, 980-986. 


\section{초록 : Streptomyces corcohrussi JK-20 유래 혈전용해효소의 순수분리 및 이의 생화학적 특성 규명}

김유정 $^{1} \cdot$ 박정욱 $^{1,2,3} \cdot$ 서민정 $^{2} \cdot$ 김민정 $^{3} \cdot$ 이혜현 $^{3} \cdot$ 진세훈 $^{1} \cdot$ 강병원 $^{1,2,3} \cdot$ 최영현 $^{4} \cdot$ 정영기 $^{1,2,3 *}$

( ${ }^{1}$ 동아대학교 생물공학과, ${ }^{2}$ 동아대학교 의학생물과학과, ${ }^{3}$ Medi-Farm 산업화 연구센터, ${ }^{4}$ 동의대학교 한의과 대학 생화학교실)

토양에서 생육하는 Streptomyces corcohrussi의 혈전용해효소가 DEAE-Sephadex A-50 그리고 Sephadex G-50 젤 여과 를 이용한 크로마토그라피 방법에 의해 순수분리 되었다. SDS-PAGE 분석결과, 분리된 효소는 단일 단백질이고, 그 분 자량은 약 $34 \mathrm{kDa}$ 이라는 것을 알 수 있었다. 순수분리된 효소의 혈전용해활성은 plasminogen-rich fibrin plate 에서 $0.8 \mathrm{U} / \mathrm{ml}$ 이었으나, plasminogen-free fibrin plate 에서의 그 효소활성은 $0.36 \mathrm{U} / \mathrm{ml}$ 이하이었다. 이러한 결과로, 순수

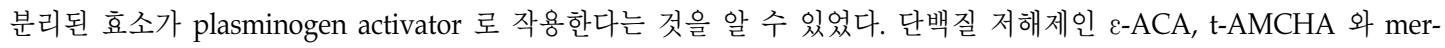
curic chloride 의 존재시에 그 혈전용해활성은 $24 \%$ 이하이었는데, 이러한 결과는 이들 plasmin 저해제 그리고(혹은) fibrinogen을 fibrin으로 전환시키는 과정과 관련된 fibrinogen 저해제에 의해 이 효소가 조절될 수 있음을 나타낼 수 있다. 한편으로, 중금속 이온인 $\mathrm{Zn}^{2+}$ 은 그 활성을 $58 \%$ 감소시켰다. 순수 분리된 효소의 최적 온도는 약 $50^{\circ} \mathrm{C}$ 이었고, 그 효소활성의 $92 \%$ 이상은 $\mathrm{pH} 5.0$ 과 8.0 사이에서 유지되었다. 그러므로, 이러한 결과들은 하나의 강력한 혈전용해효소 를 제공해서, S. corcohrussi 유래 새로운 혈전용해제의 개발에 기여하도록 한다. 